\title{
ІННОВАЦІЙНІ ТЕХНОЛОГІЇ У НАВЧАЛЬНОМУ ПРОЦЕСІ В ДЕРЖАВНОМУ ЗАКЛАДІ “ЛУГАНСЬКИЙ ДЕРЖАВНИЙ МЕДИЧНИЙ УНІВЕРСИТЕТ”
}

\author{
В. К. Івченко, В. В. Сімрок, С. М. Смірнов, В. М. Сенчій \\ Державний заклад “Луганський державний медичний університет”
}

\section{INNOVATIVE TECHNOLOGIES IN EDUCATIONAL PROCESS IN STATE INSTITUTION «LUHANSK STATE MEDICAL UNIVERSITY»}

\author{
V. K. Ivchenko, V. V. Simrok, S. M. Smirnov, V. M. Senchiy \\ State Institution "Luhansk State Medical University"
}

\begin{abstract}
У роботі представлено дані про застосування сучасних інноваційних технологій в навчальному процесі на теоретичних та клінічних кафедрах державного закладу “Луганський державний медичний університет”. Впровадження сучасних технологій дозволяс оптимізувати навчальний процес, більш ефективно використовувати час для засвосння практичних навичок, підвищувати якість отриманих студентами знань. На клінічних кафедрах застосування сучасних фантомів дає можливість викладачу моделювати різні клінічні ситуації, особливо невідкладні стани, й особливо при відсутності паціснтів із патологією, котра вивчається в клініці. Впровадження кредитно-модульної системи навчання неможливе без застосування сучасних інноваційних технологій.
\end{abstract}

In this study there is presented the information on application of modern innovative technologies in an educational process at theoretical and clinical departments of State Institution «Luhansk State Medical University». Introduction of modern technologies allows to optimize an educational process, to use time more effectively for mastering of practical skills, to improve the quality of knowledges obtained by students. At clinical departments application of modern phantoms gives a teacher a possibility to design different clinical cases, especially exigent cases and particularly in default of patients with pathology studied in a clinic. Introduction of credit-modular system is impossible without application of modern innovative technologies.

Вступ. Освіта України відповідно до руху країни в Свропу беззаперечно однозначно визначила, як основний напрям, інтеграцію в європейський освітній простір. Основна концепція медичної освіти - безперервність іï отримання. Основна мета при отриманні освіти - набуття досвіду, знань та навичок, котрі забезпечать достатній рівень духовності, професійності, достатній рівень проживання рідних та близьких. Основне завдання при реалізації даної концепції- отримання якісної та максимально доступної інформації на всіх етапах отримання знань, досвіду та навичок.

Основна частина. Існує три основних місця, де відбувається процес набуття знань. Дім, робота, навчальна лава. Поняття навчальної лави досить широке й об’ єднує в собі етапи дошкільної, шкільної, професійно-технічної та університетської освіти до етапу отримання диплома. Наше завдання - оцінити та спрогнозувати на майбутнє застосування новітніх технологій на цих етапах отримання знань. Та перш за все необхідно прояснити ситуацію із постачальником освітніх технологій. Це звичайно вчитель. В ролі вчителя на першому місці завжди буде сім'я. На пев- ному етапі отримання освітніх послуг основним учителем є батьки. На другому місці в якості учителя виступають діти для своїх батьків. I тільки тоді, коли $€$ недостатність у знаннях на цих етапах, ми звертаємось до третьої особи (рис. 1).

Але на кожному етапі використовують певні освітні технології, за допомогою яких ми отримуємо доступ до знань, навичок, за допомогою яких ми набуваємо досвід.

Якщо почати спочатку, то необхідно оцінити основні освітні технології, починаючи зі шкільної

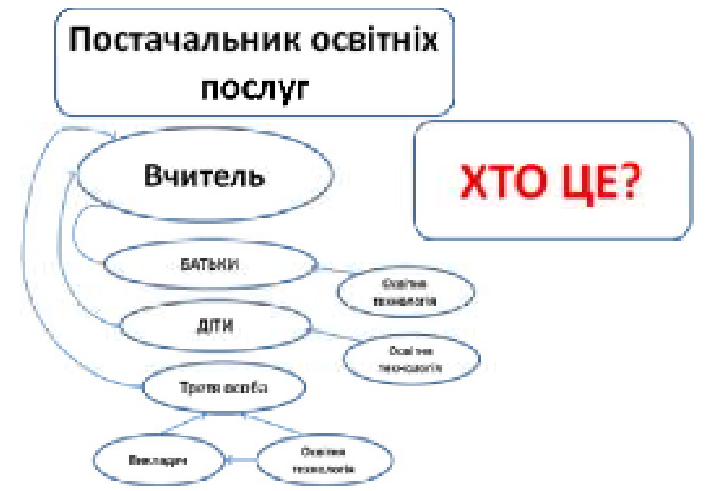

Puc. 1. Постачальники освітніх технологій. 
лави. На сучасному етапі на рівні школи використовують технології передачі інформації наших першодрукарів Святих Кирила та Мефодія. На сучасному етапі книга як паперовий носій та зошит є основними способами отримання та передачі інформації.

Але вже на сучасному етапі отримання і передачі знань та інформації все більше і більше використовують цифрові технології. Згідно з статистикою близько $20 \%$ всієї інформації, що циркулює у суспільстві, $\epsilon$ інформація на цифрових носіях, і ця ситуація має тенденцію до зсуву в бік цифри. Темпи зростання цієї тенденції ми можемо простежити на зразку еволюції

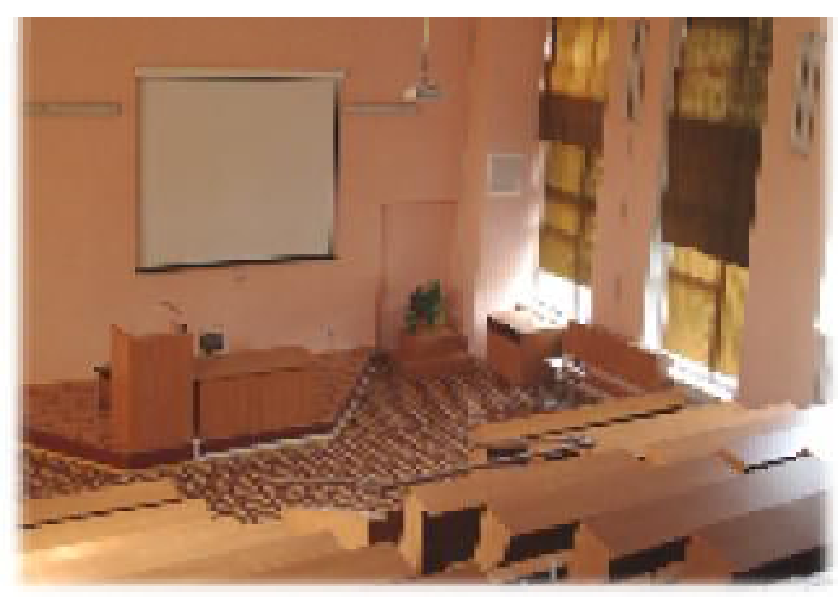

Puc. 2. Лекційна аудиторія з мультимедійним обладнанням.

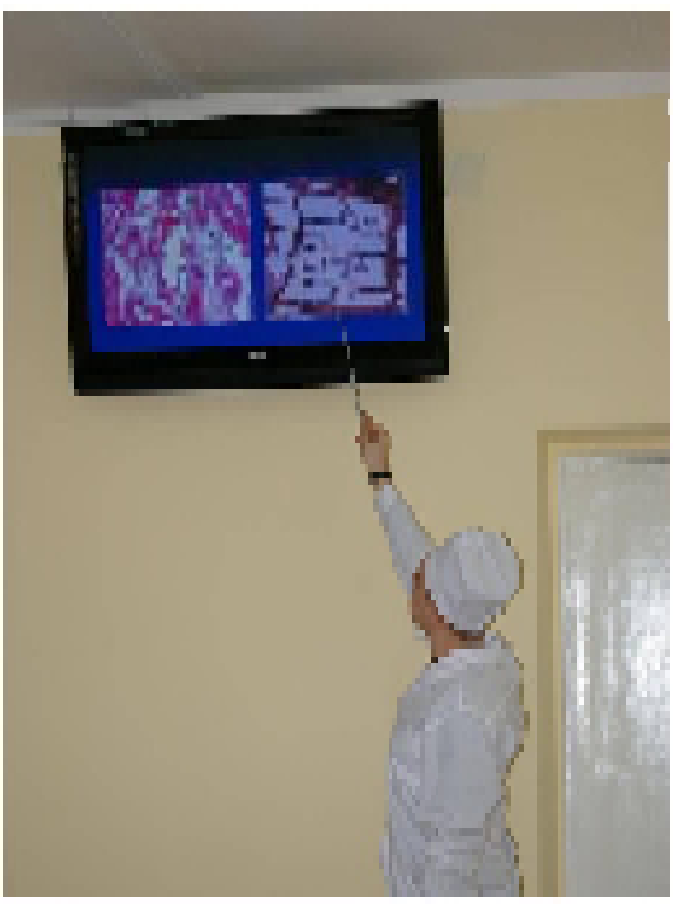

Puc. 4. У навчальних кімнатах на чотирьох кафедрах встановлено 27 мультимедійних панелей. Це значно інтенсифікувало навчальний процес. мобільних телефонів. Перший мобільний телефон було виготовлено у 1973 році, вартував 4000 доларів. Через двадцять років телефон вже мав значно більше функцій і його можна було носити вже не в рюкзаку, та його вартість складала 200-300 доларів. На даному етапі ми вже маємо практично мобільні комп'ютери, а в недалекому майбутньому нас очікують суперлегкі телефони-комп'ютери з гнучкими дисплеями. Сучасний лікар повинен володіти даними приладами для підвищення якості своїх знань, а допомогти йому в цьому повинні ми, на етапі навчання в університеті. Тому з комп'ютерною технікою ми маємо таку ситуацію в університеті.

Процес отримання знань відбувасться у навчальних лабораторіях (рис. 2-6) :

- лекційні зали;

- навчальні кімнати;

- медійні лабораторії.

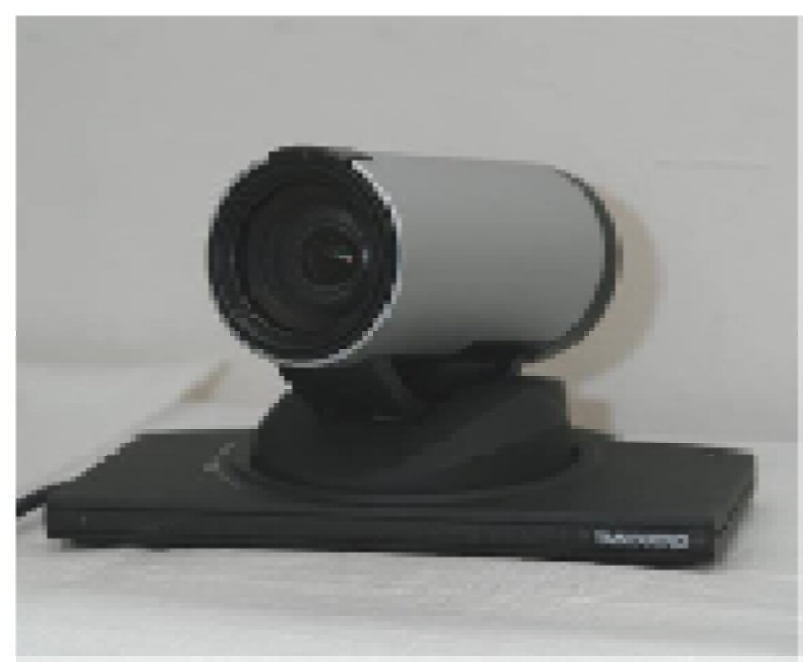

Puc. 3. У лекційних аудиторіях встановлено вебкамери, котрі дають можливість проводити он-лайн веб-конференції, відеозаписи лекцій.

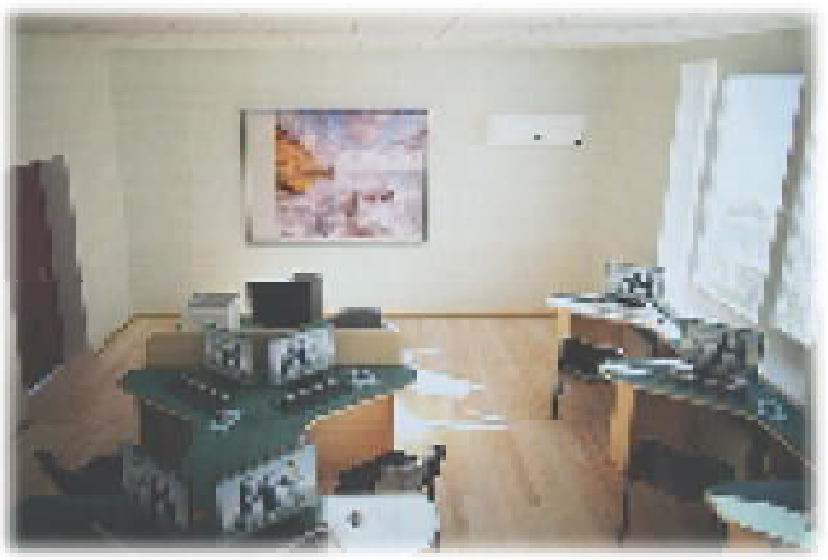

Puc. 5. Наші навчальні кімнати, а точніше деякі 3 них, відповідають міжнародним вимогам. 
У лекційних аудиторіях з метою організації та проведення веб-семінарів, веб-лекцій встановлено вебкамери. На сьогодні дана технологія почала активно використовуватись в рамках МОЗ для проведення телеконсультацій. У нашому розпорядженні $\epsilon$ висококласне устаткування, котре дозволяє проводити багатосторонні веб-конференції, консиліуми 3 приводу особливих клінічних ситуацій. Такий підхід формує у майбутнього лікаря розуміння телемедицини, розкриває ії можливості та саму методику.

Близько 1000 комп'ютерів дозволяють активно впроваджувати мультимедійні технології у навчальний процес і в процес контролю за якістю знань як під час екзаменів, так і під час практичних та семінарських занять. Сучасні комп'ютерні класи обладнані сучасними комп'ютерними системами. У найак- туальніших та напружених місцях роботи встановлено інтерактивні дошки, котрі дозволяють підвищити якість викладання та подачі матеріалу. Всі комп'ютерні класи підключені до Інтернет-мережі, що дає змогу проводити активний пошук та використання матеріалу в режимі он-лайн.

Велике значення для майбутнього медичного працівника має засвоєння цілого ряду практичних навичок, котрі неможливо отримати студентам в умовах звичайної клініки. 3 цією метою в університеті відкрито 7 спеціальних медійних лабораторій, що оснащені сучасними комп'ютеризованими манекенами, котрі дають змогу не тільки вправно оволодіти навичками, але й оцінювати майстерність засвоєних навичок. Ці лабораторії допомагають підняти на новий рівень методику викладання клінічних дисциплін.
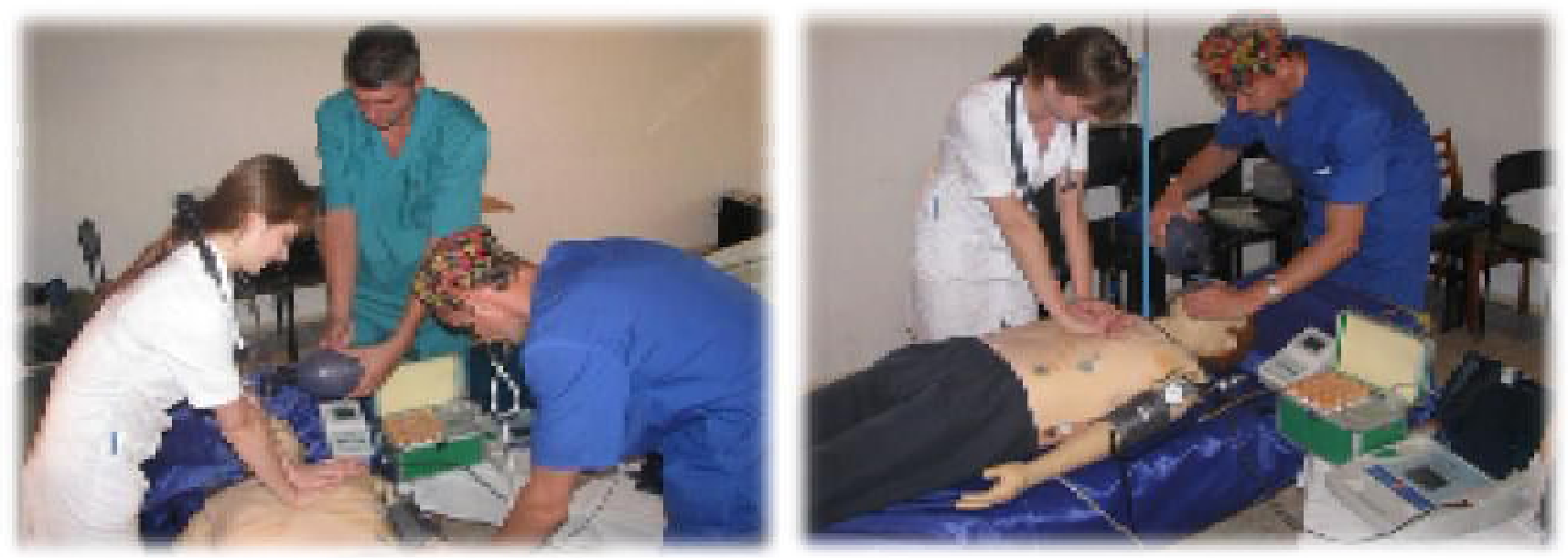

Puc. 6. Студенти набувають практичні навички на сучасному рівні.
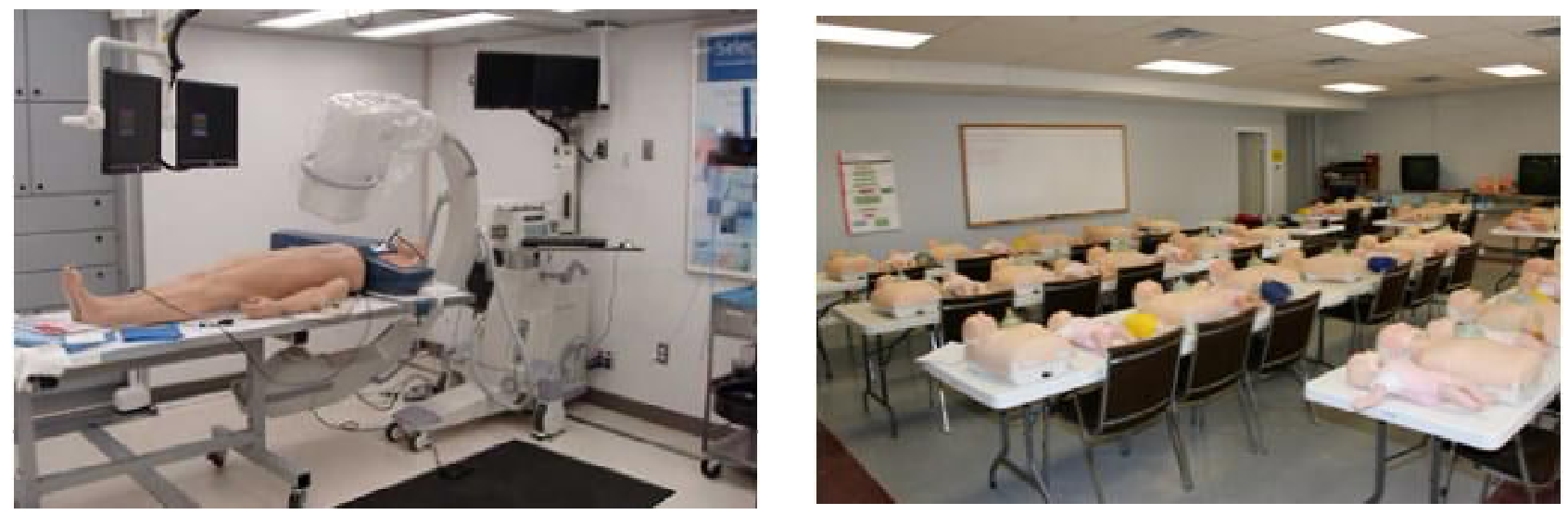

У майбутньому наші медійні лабораторії матимуть такий вигляд.

Висновок. Нашою метою буде створення медійних навчальних медичних центрів, що будуть оснащені найсучаснішим навчально-медичним устатку- ванням, котрий дасть змогу успішно конкурувати нашим випускникам не тільки на ринку праці України, а й у дальньому зарубіжжі. 